\title{
Clarias microspilus, a new walking catfish (Teleostei: Clariidae) from northern Sumatra, Indonesia
}

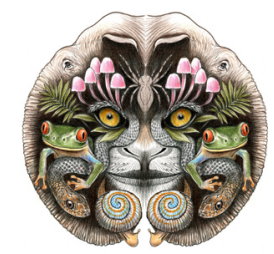

\author{
Heok Hee $\mathrm{Ng}^{1}$ \& Renny K. Hadiaty ${ }^{2}$ \\ ${ }^{1}$ Raffles Museum of Biodiversity Research, Department of Biological Sciences, National University of Singapore, 6 Science Drive 2 \\ \#03-01, Singapore 117546. \\ ${ }^{2}$ Division of Zoology, Research Center for Biology, Indonesian Institute of Sciences, Gedung Widyasatwaloka, Jalan Raya Jakarta \\ km. 46, Cibinong 16911, Indonesia. \\ Email: ${ }^{1}$ heokhee@nus.edu.sg (corresponding author), ${ }^{2}$ rkhadiaty@gmail.com
}

Date of publication (online): 26 March 2011 Date of publication (print): 26 March 2011 ISSN 0974-7907 (online) | 0974-7893 (print)

Editor: K. Rema Devi

\section{Manuscript details:}

Ms \# 02386

Received 18 January 2010

Final received 16 November 2010

Finally accepted 23 February 2011

Citation: Ng, H.H. \& R.K. Hadiaty (2011) Clarias microspilus, a new walking catfish (Teleostei: Clariidae) from northern Sumatra, Indonesia. Journal of Threatened Taxa 3(3): 1577-1584

Copyright: (c) Heok Hee Ng \& Renny K. Hadiaty 2011. Creative Commons Attribution 3.0 Unported License. JoTT allows unrestricted use of this article in any medium for non-profit purposes, reproduction and distribution by providing adequate credit to the authors and the source of publication.

Author Details: see end of this article.

Author Contribution: RKH collected part of the type series and assisted in writing the manuscript. HHN collected data and wrote the remainder of the manuscript.

Acknowledgements: We are grateful to Melanie Stiassny (AMNH), John Lundberg (ANSP), James Maclaine (BMNH), David Catania (CAS), Maurice Kottelat (CMK), Mary Anne Rogers (FMNH), Sven Kullander (NRM), Martien van Oijen (RMNH), Douglas Nelson (UMMZ), Jeffrey Williams (USNM), Isaäc Isbrücker (ZMA) and Kelvin Lim (ZRC) for permission to examine material under their care. We thank Soetikno Wirjoatmodjo who collected the first specimens from Pucuk Lembang recognizable as the new species. Thanks are also due to H.B. Munaf and T. Sim, who collected additional specimens. Financial support to RKH by a Raffles Museum of Biodiversity Research Visiting Fellowship is acknowledged.

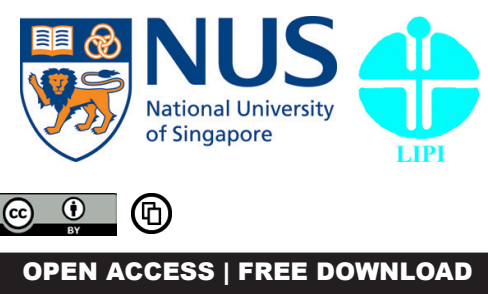

Abstract: Clarias microspilus, a new species of walking catfish is described from the short coastal rivers draining the western face of the Leuser Mountain Range and debouching into the Indian Ocean in Nangroe Aceh Darussalam province, northern Sumatra, Indonesia. It can be distinguished from Southeast Asian congeners in having a combination of the following characters: distance between the tip of the occipital process and the base of the first dorsal-fin ray 6.5-9.2 \% SL; body depth at anus 14.9-18.9 $\%$ SL; head width 18.6-21.7\% SL; head depth 12.9-16.0\% SL; interorbital distance 40.5-44.5 \% HL; occipital process width 31.7-40.8\% HL; 64-68 dorsal-fin rays; 51-56 anal-fin rays; anterior tip of frontal fontanel reaching line through middle of orbit; anterior margin of pectoral spine with 22-34 serrations and posterodorsal margin smooth.

\section{Keywords: Aceh, Alas River drainage, Ostariophysi, Southeast Asia}

Bahasa Indonesia Abstract: Clarias microspilus adalah ikan lele jenis baru yang dideskripsi dari beberapa sungai pendek di sebelah barat Gunung Leuser dan mengalir ke Samudra Hindia, di Propinsi Nangroe Aceh Darussalam, Sumatra, Indonesia. Ikan ini bisa dibedakan dari kerabatnya di Asia Tenggara dengan adanya beberapa kombinasi karakter, yaitu jarak antara ujung occipital process dan pangkal sirip punggung 6,5-9,2 $\%$ PS; tinggi badan di anus 14,9-18,9 \% PS; lebar kepala 18,6-21, 7 \% PS; tinggi kepala 12,9-16,0 \% PS; jarak antar mata 40,5-44,5 \% PK; lebar occipital process 31,7-40,8 \% PK; sirip punggung dengan 64-68 jari-jari; 51-56 jari-jari pada sirip anal; ujung fontanel depan mencapai garis tengan mata; sirip dada sebelah depan mempunyai 22-34 gerigi, sedangkan sisi belakangnya halus.

\section{INTRODUCTION}

The Old World catfish family Clariidae is a moderately diverse group of catfishes (113 species in 16 genera; Ferraris 2007). The family is diagnosed by the following autapomorphies: presence of well-developed mesial cartilage complex connecting the inner mandibular barbels at midline; pars lateralis lying completely dorsal to the pars ventralis of the protractor hyoideus; dorsolateral portion of cleithrum anterioposteriorly elongate; well-developed posterodorsal projection on the opercle; and a prominent ventrolateral crest on the anterior ceratohyal (Diogo 2007). The genus Clarias Scopoli, 1777 is the most speciose in the family Clariidae, accounting for almost half the diversity of the family (56 species; Ferraris 2007). Clarias is naturally distributed in inland water bodies in both Africa and Asia, with the bulk of the species being found in Africa. However, recent studies (e.g. Lim \& Ng 1999; Teugels et al. 2001; Sudarto et al. 2003; Ng 2004) have uncovered a greater diversity of Asian taxa than previously known. The genus has also been shown to be paraphyletic, with the Asian species of Clarias needing to be assigned to a separate genus (Teugels \& Adriaens 2003; Agnèse \& Teugels 2005). 
During ichthyological surveys of Nangroe Aceh Darussalam province in northern Sumatra, specimens of a Clarias species superficially resembling $C$. batrachus were collected. A detailed study of this material revealed them to belong to an undescribed species, which is named herein as Clarias microspilus, a new species.

\section{MATERIAL AND METHODS}

Measurements were made point to point with dial calipers and data recorded to tenths of a millimeter. Counts and measurements were made on the left side of specimens whenever possible. Vertebrae and medianfin rays were counted from radiographs, while pairedfin rays were counted under a binocular dissecting microscope. Subunits of the head are presented as proportions of head length (HL). Head length and measurements of body parts are given as proportions of standard length (SL). Measurements follow those of $\mathrm{Ng}$ (1999). Asterisks after meristic counts indicate values for holotype. Institutional acronyms follow Ferraris (2007).

\section{Clarias microspilus sp. nov. (Image 1)}

\section{Type material}

Holotype: MZB 8706, $136.1 \mathrm{~mm}$ SL; Sumatra: Nangroe Aceh Darussalam Province, Kabupaten Aceh Selatan, Sungai Lembang at Pasilembang $\left(3^{\circ} 1^{\prime} \mathrm{N}\right.$ \& 97021'E), coll. S. Wirjoatmodjo et al., 26.ii.1999.

Paratypes: MZB 4768 (3), 118.7-125.5 mm SL; ZRC 46418 (1), 127.4mm SL; Sumatra: Nangroe Aceh Darussalam province. Kabupaten Aceh Selatan, Kandang ( $3^{\circ} 6^{\prime} \mathrm{N}$ \& 97021'E), coll. H.B. Munaf, 15.xi.1982. MZB 8705 (1), 175.7mm SL; Sumatra: Nangroe Aceh Darussalam Province, Kabupaten Aceh Selatan, Sungai Lembang at Pucuk Lembang ( $\left.3^{\circ} 6^{\prime} \mathrm{N} \& 9^{0} 28^{\prime} \mathrm{E}\right)$, coll. R.K. Hadiaty \& A. Mun'im, 02.ix.1997. MZB 8713 (1), 233.2mm SL; Sumatra: Nangroe Aceh Darussalam Province, Kabupaten Aceh Selatan, swamp at Suaq Belimbing ( $3^{\circ} 4^{\prime}$ N \& 97026'E), coll. S. Wirjoatmodjo, 21.ii.1999. ZRC 51917 (4), 127.6-141.6 mm SL; Sumatra: Nangroe Aceh Darussalam Province, Kabupaten Aceh Selatan, Desa Ujung Padang, blackwater swamp along Tapaktuan-
Subulussalam road $\left(3^{0} 1{ }^{\prime} 55.2^{\prime \prime} \mathrm{N} \& 9^{0} 20^{\prime} 17.6\right.$ "E), coll. T. Sim et al., 18.iv.2009.

\section{Diagnosis}

Clarias microspilus can be distinguished from all Southeast Asian congeners, except for $C$. intermedius, C. insolitus, C. meladerma, C. olivaceus and $C$. planiceps, in having a serrated (vs. smooth or rugose, with irregular bumps) anterior margin of the pectoral spine. It differs from C. intermedius and C. meladerma by a longer distance between the tip of the occipital process and the base of the first dorsal-fin ray (6.5-9.2 $\%$ SL vs. 2.8-5.6), from C. insolitus, C. olivaceus and C. planiceps by a deeper body (14.9-18.9\% SL vs. 9.7$15.2)$ and wider head (18.6-21.7 \% SL vs. 14.0-18.7). Clarias microspilus further differs from C. intermedius in having fewer rays in the median fins (64-68 vs. 7072 dorsal-fin rays and $51-56$ vs. $61-62$ anal-fin rays), from C. insolitus in having a shorter distance between the tip of the occipital process and the base of the first dorsal-fin ray (6.5-9.2\% SL vs. 10.3-12.4), and from C. meladerma in having more serrations (22-34 vs. 14-22) on the anterior edge of the pectoral spine. It is further distinguished from C. olivaceus in having a more posteriorly situated frontal fontanel (the anterior tip of the frontal fontanel reaching to a line through the middle of the orbit vs. to anterior orbital margin), a smooth (vs. weakly serrated) posterodorsal margin of the pectoral spine, a shorter distance between the tip of the occipital process and the base of the first dorsal-fin ray (6.5-9.2\% SL vs. 9.3-11.1) and a wider occipital process (31.7-40.8\%HL vs. 25.5-31.5), and from $C$. planiceps in having a deeper head (12.9-16.0 \% SL vs. 9.5-11.5) and smaller interorbital distance (40.5-44.5 $\%$ HL vs. 46.4-49.9).

\section{Description}

Biometric data in Table 1. Head depressed; dorsal profile slightly convex and ventral profile almost straight. Bony elements of dorsal surface of head covered with thick skin; bones not readily visible, but sutures sometimes evident. Anterior pair of nostrils tubular and medial to maxillary barbel base. Posterior pair of nostrils bordered by nasal barbels anteriorly and fleshy membrane posteriorly; posteromedial to maxillary barbel base. Eye ovoid, horizontal axis longest, subcutaneous; located dorsolaterally on head. Anterior fontanel short and squat ("shoe-shaped" of 
Teugels, 1986); anterior tip reaching to line through middle of orbits. Occipital process rounded. Gill openings narrow, extending from dorsal-most point of pectoral-fin base to isthmus. Gill membranes free from isthmus but united to each other with $8(n=5)$ branchiostegal rays. First branchial arch with $5+13$ $(\mathrm{n}=2)$ or $5+14 *(\mathrm{n}=3)$ gill rakers.

Mouth subterminal, with fleshy, plicate lips. Oral teeth small and in irregular rows on all tooth-bearing surfaces. Premaxillary tooth band rectangular, with median notch on posterior edge. Dentary tooth band much narrower than premaxillary tooth band at symphysis, tapering laterally. Vomerine tooth band unpaired, continuous across midline, crescentic and smoothly arched along anterior and posterior margins. Premaxillary and dentary teeth viliform; vomerine teeth subgranular. Barbels in four pairs; long and slender with thick fleshy bases. Maxillary barbel extending to base of fifth or sixth dorsal-fin ray. Nasal barbel, extending nearly to level of base of last pectoral-fin ray. Inner mandibular-barbel origin close to midline; barbel thicker and longer than nasal barbel and extending beyond base of last pectoral-fin ray. Outer mandibular barbel originating posterolateral to

Table 1. Biometric data for Clarias microspilus $(n=11)$.

\begin{tabular}{|c|c|c|c|}
\hline & Holotype & Range & Mean \pm SD \\
\hline \multicolumn{4}{|l|}{$\% S L$} \\
\hline Predorsal length & 36.4 & $31.4-36.4$ & $33.8 \pm 1.91$ \\
\hline Preanal length & 49.0 & $49.0-55.0$ & $51.7 \pm 2.13$ \\
\hline Prepelvic length & 42.4 & $42.4-46.7$ & $44.5 \pm 1.71$ \\
\hline Prepectoral length & 22.0 & $20.3-24.3$ & $22.3 \pm 1.54$ \\
\hline Length of dorsal-fin base & 68.3 & $64.7-69.0$ & $67.3 \pm 1.71$ \\
\hline Anal-fin length & 48.6 & $47.4-50.5$ & $49.2 \pm 1.21$ \\
\hline Pelvic-fin length & 10.9 & $9.2-10.9$ & $9.8 \pm 0.66$ \\
\hline Pectoral-fin length & 17.0 & $12.7-17.2$ & $14.9 \pm 1.94$ \\
\hline Pectoral-spine length & 12.5 & $9.2-12.5$ & $10.5 \pm 1.16$ \\
\hline Caudal-fin length & 18.7 & $14.3-19.2$ & $17.2 \pm 1.75$ \\
\hline $\begin{array}{l}\text { Distance between occipital } \\
\text { process and dorsal fin }\end{array}$ & 8.9 & $6.5-9.2$ & $7.9 \pm 1.07$ \\
\hline Body depth at anus & 18.9 & $14.9-18.9$ & $17.2 \pm 1.48$ \\
\hline Caudal peduncle depth & 8.1 & $7.7-9.4$ & $8.4 \pm 0.62$ \\
\hline Head length & 28.1 & $25.3-28.1$ & $26.9 \pm 0.94$ \\
\hline Head width & 21.7 & $18.6-21.7$ & $19.8 \pm 1.04$ \\
\hline Head depth & 15.5 & $12.9-16.0$ & $14.6 \pm 1.18$ \\
\hline \multicolumn{4}{|l|}{$\% \mathrm{HL}$} \\
\hline Snout length & 31.2 & $26.6-32.0$ & $29.4 \pm 2.09$ \\
\hline Interorbital distance & 44.0 & $40.5-44.5$ & $43.0 \pm 1.42$ \\
\hline Eye diameter & 6.3 & $6.0-7.2$ & $6.3 \pm 0.43$ \\
\hline Frontal fontanel length & 17.3 & $11.5-17.3$ & $14.4 \pm 2.16$ \\
\hline Frontal fontanel width & 3.4 & $3.4-6.7$ & $5.3 \pm 1.15$ \\
\hline Occipital fontanel length & 8.4 & $7.1-12.8$ & $9.6 \pm 1.80$ \\
\hline Occipital fontanel width & 4.2 & $3.9-5.7$ & $4.8 \pm 0.61$ \\
\hline Occipital process length & 9.4 & $7.7-14.8$ & $11.0 \pm 2.39$ \\
\hline Occipital process width & 40.8 & $31.7-40.8$ & $36.8 \pm 3.47$ \\
\hline Nasal barbel length & 105.0 & $84.0-105.0$ & $94.8 \pm 7.17$ \\
\hline Maxillary barbel length & 143.7 & $128.0-154.9$ & $139.8 \pm 11.30$ \\
\hline Inner mandibular barbel length & 91.1 & $83.3-97.1$ & $90.7 \pm 5.80$ \\
\hline Outer mandibular barbel length & 123.6 & 110.3-130.6 & $121.6 \pm 7.52$ \\
\hline
\end{tabular}




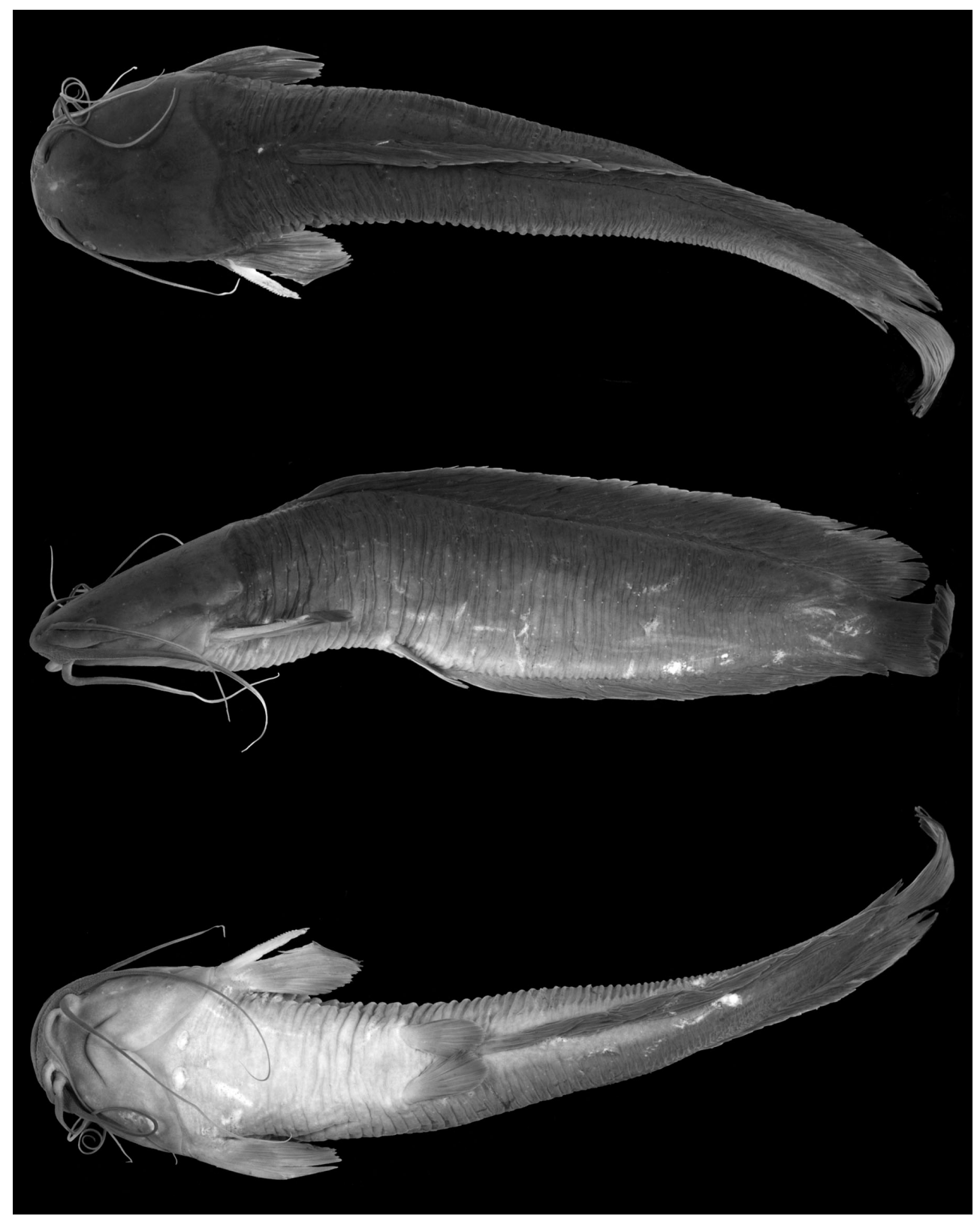

Image 1. Clarias microspilus sp. nov., MZB 8706, holotype, 136.1mm SL; Sumatra: Aceh, Sungai Lembang.

inner mandibular barbel, extending nearly to base of first pelvic-fin ray.

Body cylindrical, becoming compressed towards caudal peduncle. Dorsal profile rising very gently from tip of snout to origin of dorsal fin and thereafter almost horizontal to end of caudal peduncle. Ventral profile slightly convex to middle of head and thereafter almost horizontal to end of caudal peduncle. Skin smooth. Lateral line complete and midlateral in position. Vertebrae $20+40=60^{*}(n=1), 19+42=61 \quad(n=3)$, or $20+42=62(\mathrm{n}=1)$.

Dorsal fin with long base, spanning posterior three- quarters of body; with $64 *(n=1), 66(n=3)$, or $68(n=1)$ rays covered by thick layer of skin and without spine.

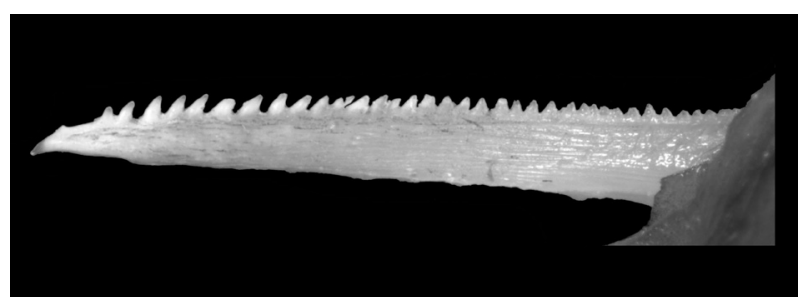

Image 2. Left pectoral spine of C. microspilus, MZB 8705, paratype, $175.7 \mathrm{~mm} \mathrm{SL}$. 
Dorsal-fin margin straight, parallel to dorsal edge of body. Pectoral fin with small spine, sharply pointed at tip, and 8, $(\mathrm{n}=5)$ rays. Almost entire length of anterior spine margin with 22-34 prominent serrations; posterior spine margin smooth or with uneven asperities (Image 2). Pectoral-fin margin straight anteriorly, convex posteriorly. Pelvic-fin origin at anterior third of body, with i,5 $(n=5)$ rays and convex margin; tip of adpressed fin reaching base of first two or three anal-fin rays. Anus and urogenital openings located at vertical through middle of adpressed pelvic fin. Anal fin with long base and $51^{*}(n=1), 54(n=2)$, or $56(n=2)$ rays covered by thick layer of skin; margin straight and parallel to ventral edge of body. Caudal peduncle very short. Caudal fin rounded, with i,7,7,i $(n=5)$ principal rays.

\section{Coloration}

In $70 \%$ ethanol: Dorsal and lateral surfaces of head and body violet-gray, fading to pale gray on ventral surfaces. Dorsal, anal and caudal fins violet-gray with very thin hyaline distal margin. Pectoral-fin rays violet-gray, with hyaline interradial membranes. Pelvic fins hyaline. Barbels and pectoral spines violetgray dorsally and light grey ventrally.

\section{Distribution}

Known from the short coastal rivers that drain the western face of the Leuser Mountain Range (Fig. 1).

\section{Etymology}

From the Greek, mikros, meaning small, and, spilos, meaning spot. The name is used in reference to the very small white spots arranged in a longitudinal and several transverse series on the body.

\section{DISCUSSION}

Among Southeast Asian Clarias, Clarias microspilus further differs from members of the $C$. nieuhofii group (C. nieuhofii, $C$. nigricans and $C$. pseudonieuhofii) in having a shorter, deeper body (depth at anus 14.9-18.9\% SL vs. 8.7-13.0) with fewer vertebrae (60-62 vs. 74-82), dorsal- (64-68 vs. $82-106)$ and anal-fin (51-56 vs. $74-87)$ rays, and the median fins separate from (vs. confluent with) the caudal fin. It is further distinguished from $C$. anfractus in having a deeper caudal peduncle (7.7-9.4\% SL vs. 6.4-7.3), broader occipital process $31.7-40.8 \% \mathrm{HL}$ vs. 22.0-28.2), fewer dorsal- (64-68 vs. 71-77) and anal-fin (51-56 vs. 57-62) rays and the white spots on the body very small and almost invisible (vs. large and prominent), from $C$. batrachus in having a deeper body (depth at anus 14.9-18.9 \% SL vs. 12.5-15.9) and broader occipital process $(31.7-40.8 \%$ HL vs. 26.1-30.7), from C. batu in having a deeper body (depth at anus 14.9-18.9 \% SL vs. 9.0-11.4) with fewer vertebrae (60-62 vs. 67-71), and anal-fin rays (51-56 vs. 61-70), from C. kapuasensis in having a

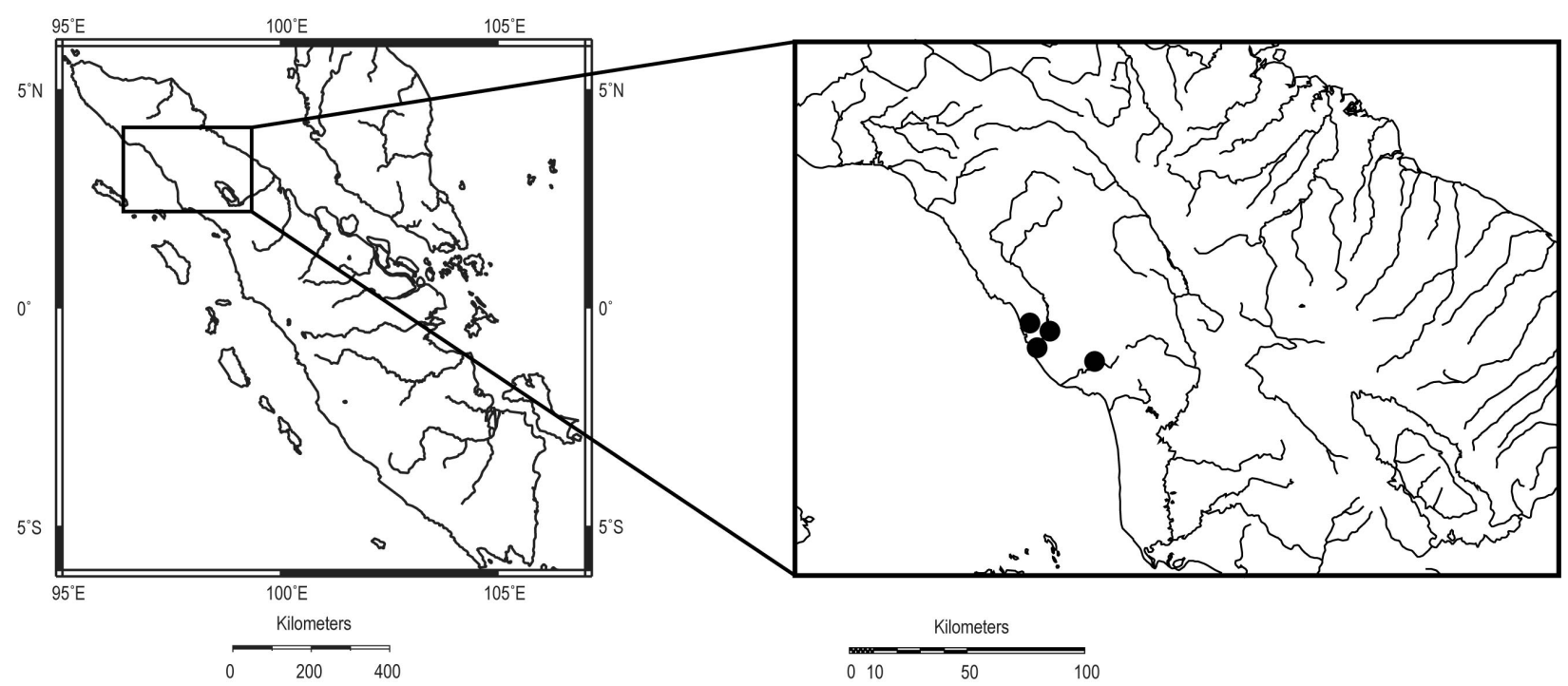

Figure 1. Collection localities of Clarias microspilus. 
wider head (18.6-21.7 \% SL vs. 16.9-18.8), longer occipital process (7.7-14.8\% HL vs. 5.2-6.6) and the white spots on the body very small and almost invisible (vs. large and prominent), and from $C$. leiacanthus in having a shorter distance between the tip of the occipital process and the base of the first dorsal-fin ray (6.5-9.2\% SL vs. 8.1-11.7). Clarias microspilus further differs from $C$. macrocephalus in having a longer distance between thetip of the occipital process and the base of the first dorsal-fin ray (6.5-9.2 $\%$ SL vs. 3.7-4.7), from C. microstomus in having a deeper body (depth at anus 14.9-18.9\% SL vs. 13.013.5), shorter distance between the tip of the occipital process and the base of the first dorsal-fin ray (6.5-9.2 \% SL vs. 12.8-13.1), wider head (18.6-21.7 \% SL vs. 16.2-17.2), narrower interorbital distance (40.5-44.5 \% HL vs. 46.7-50.2), from C. pseudoleiacanthus in having a longer distance between the tip of the occipital process and the base of the first dorsal-fin ray (6.5-9.2 $\%$ SL vs. 4.5-5.6), and from C. sulcatus in having a deeper head (12.9-16.0 \% SL vs. 10.6-12.9), broader occipital process $31.7-40.8 \%$ HL vs. 26.3-27.9), and fewer anal-fin rays (51-56 vs. 56-64).

Besides the species mentioned in the diagnosis, there are four species of Asian Clarias with a serrated anterior edge of the pectoral spine ( $C$. brachysoma, $C$. dussumieri, C. fuscus, and C. magur). These species are not found in Sundaic Southeast Asia, and brief comparisons are made with the new species below. Clarias microspilus differs from C. brachysoma (from Sri Lanka) and $C$. dussumieri (from southern India) in having a shorter distance between the tip of the occipital process and the base of the first dorsal-fin ray (6.5-9.2 \% SL vs. 9.0-11.1). Clarias microspilus is distinguished from C. fuscus (from northeastern Laos, northern Vietnam, China, Taiwan and Japan) in having more anal-fin rays (51-56 vs. 43-52), a longer distance between the tip of the occipital process and the base of the first dorsal-fin ray $(6.5-9.2 \%$ SL vs. 4.8-6.5) and broader occipital process (31.7-40.8 $\%$ HL vs. 26.7-30.0), and from C. magur (from the Indian subcontinent) in having a short and squat (vs. long and thin; "sole-shaped" vs. "knife-shaped") anterior fontanel.

We have examined material from the Alas River drainage (which drains the eastern face of the Leuser Mountain Range) that is not conspecific with $C$. microspilus. These specimens differ from the type series of $C$. microspilus in having a long and thin ("knife-shaped" vs. short and squat, "sole-shaped") frontal fontanel and the presence of irregular asperities (vs. serrations) on the anterior edge of the pectoralfin spines. Current evidence indicates the Alas River material is conspecific with material from Java identified as C. batrachus (fide $\mathrm{Ng} \&$ Kottelat, 2008).

\section{Comparative Material}

Clarias anfractus: ZRC 42598 (holotype), 176.4 mm SL; ZRC 43392 (2 paratypes), 140.4-151.9 mm SL; Borneo: Sabah, Danum, forest stream $600 \mathrm{~m}$ into conservation area, tributary of Sungai Segama. FMNH 68095 (2 paratypes), 166.3-172.1 mm SL; FMNH 68096 (1 paratype), 204.2mm SL; Borneo: Sabah, Tawau district, Kalabakan, Sungai Tibas camp, Sungai Tawan, $4^{0} 25^{\prime} \mathrm{N} \& 117^{\circ} 28^{\prime} \mathrm{E}$.

C. batrachus: NRM 54718 (neotype), $174.1 \mathrm{~mm}$ SL; UMMZ 155807 (3), 168.0-215.0 mm SL; Java: vicinity of Bandung. UMMZ 70684 (1), 101.2mm SL; Java: Kali Mandiku Jember. UMMZ 155704 (3), 193.1-206.2 mm SL; Java: vicinity of Bogor. UMMZ 155708 (3), 136.8-153.0 mm SL; UMMZ 155710 (5), 55.3-139.0 mm SL; UMMZ 155711 (5), 162.0-209.0 mm SL; Java: Ranu Lamongan, lake at Klakah. UMMZ 155709 (1), 172.2mm SL; Java: Ranu Klidungan. UMMZ 155801 (1), 116.6mm SL; Java: Cikedang, tributary to Citanduy, $1.5 \mathrm{~km} \mathrm{~N}$ of Ciawi. UMMZ 155802 (2), 128.7-131.9 mm SL; Java: Ciwalen, tributary of Citanduy at Godebak between Panaunbangan and Panjalu. UMMZ 155803 (5), 128.0-152.0 mm SL; Java: vicinity of Singaparna. UMMZ 155805 (3), 81.8-159.7 mm SL; Java: Citi' is (creek), just below road near mouth in Cimanuk, $3 \mathrm{~km}$ $\mathrm{N}$ of Garut. UMMZ 155806 (3), 153.6-183.9 mm SL; Java: vicinity of Jakarta. UMMZ 155809 (1), $187.5 \mathrm{~mm}$ SL; Java: vicinity of Tasikmalaja. UMMZ 213398 (1), 170.4mm SL; Java: vicinity of Bobotsari (near Gunung Slamet). ZRC 2585 (4), 170.1-244.8 mm SL; Java: Cilebut.

C. batu: ZRC 40087 (holotype), 245.0mm SL; ZRC 40088 (8 paratypes), 101.3-228.0 mm SL; Malaysia: Pulau Tioman, Sungai Baharu, on right side of TekekJuara trail. - ZRC 40089 (9 paratypes), 179.0-305.0 mm SL; Malaysia: Pulau Tioman, Sungai Nipah.

C. brachysoma: ZRC 41607 (1), 94.8mm SL; Sri Lanka: Galle District, Kanneliya forest.

C. dussumieri: MNHN B-0687 (syntype), 222mm 
SL; India: Mahé (photograph examined).

C. fuscus: UMMZ 100586 (1), 188.0mm SL; China: Canton. ZRC 43356 (1), 234.0mm SL; China: Fujian province, Fuzhou. ZRC 51957 (1), 91.2mm SL; China: Hainan Island, stream on road from Shibi to Wanquan. ZRC 51958 (2), 110.8-156.7 mm SL; Vietnam: Da Nang province, Song Thuy Loan drainage, Suoi Lanh, feeder stream to Suoi Mo, Ban Na foothills. ZRC 43333 (3), 155.4-169.4 mm SL; Vietnam: Hung Yen province, market at Hung Yen. Additional data from Arai \& Hirano (1974).

C. insolitus: MZB 6112 (holotype), 122.5mm SL; BMNH 2001.1.15.98-103 (7 paratypes), 53.5-139.7 mm SL; Borneo: Kalimantan Tengah, Barito River drainage; small stream flowing into Sungai Rekut (tributary of Sungai Busang) about $1.5 \mathrm{~km}$ upstream from the Project Barito Ulu base camp on Sungai Busang.

C. intermedius: ZRC 46110 (1 paratype), $192.5 \mathrm{~mm}$ SL; ZRC 46111 (1 paratype), 186.4mm SL; ZRC 46112 (1 paratype), 175.4mm SL; ZRC 46113 (1 paratype), 174.0mm SL; Borneo: Kalimantan Tengah, Kereng Bengkirai.

C. kapuasensis: Data from Sudarto et al. (2003).

C. leiacanthus: AMNH 217796 (1), 168.9mm SL; Malaysia: Selangor, small stream $800 \mathrm{~m}$ from road junction to Batu Arang on Rawang-Kuala Selangor road. ZRC 2596 (2), 93.4-109.5 mm SL; Malaysia: Pahang, Kuala Tahan. ZRC 11678-11679 (2), 109.8-
202.9 mm SL; Singapore: Nee Soon Swamp Forest. ZRC 25669 (1), 124.8mm SL; Malaysia: Pahang, $69 \mathrm{~km}$ on Mersing-Kuantan road. ZRC 37758 (10), 49.1-129.5 mm SL; Borneo: Sarawak, Bako National Park, Ulu Assam, stream I. ZRC 39105 (4), 37.0-150.0 mm SL; Sumatra: Riau, stream near Pangkalankasai, $43 \mathrm{~km}$ from Rengat on Rengat-Jambi road. ZRC 39961 (2), 56.9-120.7 mm SL; Malaysia: Johor, 3-4 km towards Kukup after Sri Bunian turnoff. ZRC 39985 (5), 23.8-177.5 mm SL; Malaysia: Johor, Pontian, Kampung Parit Tekong. ZRC 40131 (1), 97.7mm SL; Java: Java Barat, Bogor, tributary of Cipinang Gading. ZRC 40267 (3), 89.7-109.0 mm SL; Borneo: Brunei, Belait district, Sungai Sepam, draining into Sungai Ingei. ZRC 43244 (2), 111.8-125.9 mm SL; Sumatra: Sumatera Selatan, Sungai Sentang.

C. macrocephalus: ZRC 30465 (1), 223.7mm SL; Malaysia: Pahang, Sungai Jelai. ZRC 43825 (5), 125.9-160.4 mm SL; Thailand: Narathiwat province, market at Sungai Kolok.

C. magur: UMMZ 187861 (3), 210.7-212.7 mm SL; Bangladesh: Comilla, pond at Hajiganj, $29 \mathrm{~km}$ north of Chandpur. UMMZ 208609 (1), 163.3mm SL; Bangladesh: Kunti Choumaham, PS Kaska, roadside ditch $27 \mathrm{~km}$ south of Brahmabaria. UMMZ 208766 (1), 147.8mm SL; Bangladesh: Piyain Gang River below Sangram, $3 \mathrm{~km}$ below bridge at Indian border. UMMZ 244686 (1), $183.1 \mathrm{~mm}$ SL; India: West Bengal, market at Mathabhanga.

\section{Key to the species of Clarias known from Sumatra}

$1 \quad$ Pectoral spine with regular serrations on anterior margin .............................................................. Pectoral spine smooth or with irregular bumps on anterior margin ..................................................... 4

2 Distance between tip of occipital process and base of first dorsal-fin ray 6.5-11.1\% SL; 22-34 serrations on anterior edge of pectoral spine; body typically without irregular black blotches ....................................... Distance between tip of occipital process and base of first dorsal-fin ray $2.8-3.7 \%$ SL; $14-22$ serrations on anterior edge of pectoral spine; body typically with irregular black blotches ............................ meladerma

3 Anterior tip of frontal fontanel reaching line through middle of orbit; posterodorsal margin of pectoral spine smooth; body depth at anus $14.9-18.9 \%$ SL; head width $18.6-21.7 \%$ SL; distance between tip of occipital process and base of first dorsal-fin ray $6.5-9.2 \%$ SL; occipital process width $31.7-40.8 \% \mathrm{HL}$.

c. microspilus sp. nov. Anterior tip of frontal fontanel reaching through anterior orbital margin; posterodorsal margin of pectoral spine weakly serrated; body depth at anus $13.4-15.2 \%$ SL; head width $16.0-18.7 \%$ SL; distance between tip of occipital process and base of first dorsal-fin ray $9.3-11.1 \% \mathrm{SL}$; occipital process width $25.5-31.5 \% \mathrm{HL} \ldots \ldots$. C. olivaceus

Bodyvery elongate, with 74-81 totalvertebrae, 85-100 dorsal-fin rays and 73-91 anal-fin rays.......C. nieuhofii Body moderately elongate, with 54-71 total vertebrae, $62-74$ dorsal-fin rays and $47-60$ anal-fin rays....... 5

5 Distance between tip of occipital process and base of first dorsal-fin ray 5.4-6.5; anterior profile of head ovoid when viewed dorsally; frontal fontanel long and thin............................................................. batrachus Distance between tip of occipital process and base of first dorsal-fin ray $7.1-10.9 \%$ SL; anterior profile of head gently curved when viewed dorsally; frontal fontanel short and squat...... 
C. meladerma: ZRC 38979 (6), 172.8-185.5 mm SL; Sumatra: Jambi, Pasar, Angso Duo. ZRC 40798 (2), 85.3-105.9 mm SL; Thailanad: Chantaburi Province, downstream of Nam Tok Phliu 12031'14.0”'N \& $102^{0} 10^{\prime} 36.1^{\prime \prime} \mathrm{E}$.

C. microstomus: MZB 9336 (holotype), 122.9mm SL; ZRC 45776 (8 paratypes), 96.1-130.0 mm SL; Borneo: Kalimantan Timur, Kayan river drainage, Ladang near Sungai Pingai, $2^{\circ} 0$ '9.6”N \& 115'9'13.8'E.

C. nigricans: MZB 10705 (holotype), 307.5mm SL; ZRC 45590 (2 paratypes), 197.4-315.1 mm SL; Borneo: Kalimantan Timur, market in Samarinda. ZMA 121.631 (5 paratypes), 232.4-305.0 mm SL; Borneo:Kalimantan Timur, Samarinda.

C. olivaceus: ANSP 27280 (holotype), 241.8mm SL; ANSP 27281 (3 paratypes), 157.5-209.5 mm SL; Sumatra: Padang. CAS 108051 (1), 216.0mm SL; USNM 193033 (9), 113.0-149.8 mm SL; Sumatra: Lake Toba at Prapat. ZRC 41697 (8), 116.2-231.7 mm SL; ZRC 43236 (2), 204.8-222.1 mm SL; Sumatra: Jambi province, Kerinci, Sungai Penuh market.

C. planiceps: FMNH 68103 (22 paratypes), 70.8 210.8 mm SL; Borneo: Sarawak, Third Division, tributary of Baleh River, between Sungai Entunau and Sungai Putai. USNM 323727 (1 paratype), 297.3mm SL; Borneo: Sarawak, Batang Balui, tributary stream, Batang Belahui.

C. pseudoleiacanthus: Data from Sudarto et al. (2003).

C. pseudonieuhofii: Data from Sudarto et al. (2004).

C. sulcatus: ZRC 22665 (holotype), $180.5 \mathrm{~mm} \mathrm{SL}$; ZRC 22666 (1 paratype), 207.0mm SL; Malaysia: Terengganu, Pulau Redang, stream on east slope of west ridge. ZRC 22717 (1 paratype), 96.5mm SL; Malaysia: Terengganu, Pulau Redang, stream behind Pasir Panjang on east slope of east ridge.

\section{REFERENCES}

Agnèse, J.F. \& G.G. Teugels (2005). Insight into the phylogeny of African Clariidae (Teleostei, Siluriformes): Implications for their body shape evolution, biogeography, and taxonomy. Molecular Phylogenetics and Evolution 36(3): 546-553.

Arai, R. \& H. Hirano (1974). First record of the clariid catfish, Clarias fuscus, from Japan. Japanese Journal of Ichthyology 21(2): 53-60.
Diogo, R. (2007). Morphological Evolution, Adaptations, Homoplasies, Constraints and Evolutionary Trends. Catfishes as a Case Study on General Phylogeny and Macroevolution. Science Publishers, Enfield, $\mathrm{x}+491 \mathrm{pp}$.

Ferraris, C.J. (2007). Checklist of catfishes, recent and fossil (Osteichthyes, Siluriformes) and catalogue of siluriform primary types. Zootaxa 1418: 1-628.

Lim, K.K.P. \& H.H. Ng (1999). Clarias batu, a new species of catfish (Teleostei: Clariidae) from Pulau Tioman, Peninsular Malaysia. The Raffles Bulletin of Zoology Supplement 6: 157-167.

Ng, H.H. (1999). Two new species of Clarias from Borneo (Teleostei: Clariidae). The Raffles Bulletin of Zoology 47(1): 17-32.

Ng, H.H. (2004). Clarias sulcatus, a new walking catfish (Teleostei: Clariidae) from Pulau Redang. Ichthyological Exploration of Freshwaters 15(4): 289-294.

Ng, H.H. \& M. Kottelat (2008). The identity of Clarias batrachus (Linnaeus, 1758), with the designation of a neotype (Teleostei: Clariidae). Zoological Journal of the Linnean Society 153(4): 725-732.

Sudarto, G.G. Teugels \& L. Pouyaud (2003). Description of two new Clarias species from Borneo (Siluriformes, Clariidae). Cybium 27(2): 153-161.

Sudarto, G.G. Teugels \& L. Pouyaud (2004). Description of a new clariid catfish, Clarias pseudonieuhofii from West Borneo (Siluriformes: Clariidae). Zoological Studies 43(1): 8-19.

Teugels, G.G. (1986). A systematic revision of the African species of the genus Clarias (Pisces; Clariidae). Annales $d u$ Musee Royal de l'Afrique Centrale (Zoologie) 247: 1-199.

Teugels, G.G. \& D. Adriaens (2003). Taxonomy and phylogeny of Clariidae. An overview, pp. 465-487. In: Arratia, G., A.S. Kapoor, M. Chardon \& R. Diogo (eds.). Catfishes. Volume I. Science Publishers, Enfield, xvi+487pp.

Teugels, G.G., Sudarto \& L. Pouyaud (2001). Description of a new Clarias species from Southeast Asia based on morphological and genetic evidence (Siluriformes, Clariidae). Cybium 25(1): 81-92.

Author Details: Heok HeE Ng graduated with a PhD from the University of Michigan in 2006 and has been working on the taxonomy of Asian catfishes since 1994. Now at the Raffles Museum of Biodiversity Research in Singapore, his current research focus is on sisoroid taxonomy and systematics. RENNY HADIATY was awarded her bachelor's degree from the University of General Soedirman at Central Java in 1985. She has been on the research staff of The Research Center for Biology since, working on Southeast Asian freshwater fish diversity. She has been involved in several collecting expeditions in Sumatra, Kalimantan, Sulawesi and Papua, and having described more than 20 fish species. 